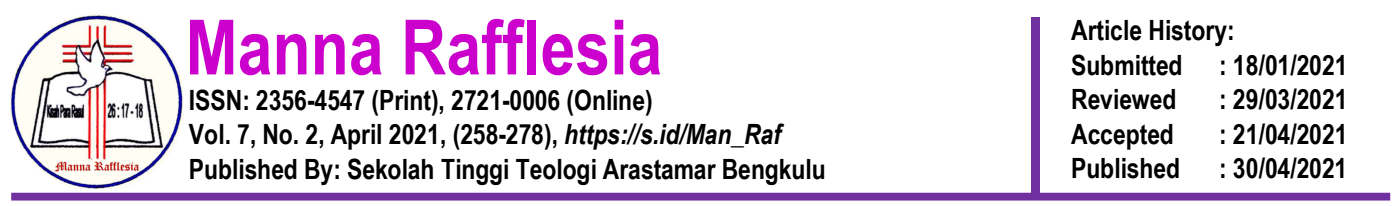

\title{
TINJAUAN TEOLOGIS TERHADAP PANDEMI CORONAVIRUS DISEASE 2019 DALAM PRINSIP PEMBALASAN
}

\author{
Efesus Suratman ${ }^{1}$ ) \\ Sekolah Tinggi Teologi Bethel Indonesia ${ }^{1}$ \\ *)Email Correspondence: Efesus@sttbi.ac.id
}

\begin{abstract}
Many people expect a good, healthy, prosperous life, do not experience suffering. People who have a prosperous, healthy life, without suffering are usually identified with people who are obedient and fear God, where the concept of fearing God gets blessings and does not get curses, suffering, or other bad things that are often referred to as the principle of retaliation. This principle of retaliation is a common and believed principle from time to time. In wisdom literature, the principle of retaliation is one of the points that need attention. But in fact there are many who are pious, fearing God, whether they experience suffering that is not appropriate. This research approach is qualitative using a theological approach that can be used to understand the gaps that occur, the concept of the principle of retribution cannot be established in general terms and can be stated inaccurately if it is addressed to righteous people, pious people, good people, and suffering children, because the theory stated by the facts that occurs is incompatible and very contradictory.
\end{abstract}

Keywords: $\quad$ Pandemi Covid-19, Principle of Retaliation

Abstrak: Banyak orang yang mengharapkan kehidupan yang baik, sehat, sejahtera, tidak mengalami penderitaan. Orang-orang yang hidupnya berkemakmuran, sehat, penderitaan biasanya mereka dianggap sebagai orang yang takut akan Tuhan dan taat, dimana konsep takut akan Tuhan mendapat berkat dan tidak mendapatkan kutuk, penderitaan, atau hal-hal yang tidak baik lainnya yang sering disebut dengan prinsip pembalasan. Prinsip pembalasan ini adalah prisip yang lazim dan dipercaya dari masa ke masa, dalam sastra hikmat prinsip pembalasan menjadi salah satu point yang perlu diperhatikan. Namun pada faktanya banyak juga yang saleh, takut akan Tuhan, baik mereka mengalami penderitaan yang tidak pada tempatnya. Pendekatan penelitian ini adalah kualitatif menggunakan pendekatan tinjauan teologis dapat digunakan untuk memahami gap yang terjadi, konsep prinsip pembalasan tidaklah dapat ditetapkan secara general dan dapat dinyatakan kurang tepat jika ditujukan kepada orang benar, orang saleh, orang baik, anak kecil yang menderita, karena teori yang dinyatakan dengan fakta yang terjadi ada tidak sesuai dan sangat bertentangan.

Kata Kuci: $\quad$ Pandemi Covid-19, Prinsip Pembalasan

\section{PENDAHULUAN}

Setiap manusia memiliki pengharapan dalam kehidupan seperti memiliki

hidup yang sejahtera, bahagia, terhindar dari masalah, selalu beruntung, hidup

yang nyaman dalam berbagai macam aspek, terlebih lagi dalam aspek kesehatan 
dan ekonomi yang dapat dikatakan sebagai faktor utama penentu kebahagiaan. Selanjutnya Took Hammond menuliskan bahwa orang miskin materi cenderung tersisihkan, tidak dianggap, tidak didengarkan sekalipun memiliki hikmat dan tidak dipercaya karena jika memang berhikmat tentu tidak miskin. ${ }^{1}$ Rene Girard mengatakan bagi kebanyakan masyarakat kuno, prinsip klasik hidup ini meyakini bahwa Allah (atau dewa-dewa) memiliki aturan secara moral yang harus dipatuhi dan dijalankan oleh manusia untuk mendapatkan imbalan sesuai dengan yang telah dilakukan. ${ }^{2}$ Dengan demikian hubungan antara manusia dengan Tuhan memberikan dampak bagi kehidupan manusia, baik dalam hal kesehatan dan kesejahteraan hidup. Orang yang dikatakan "berhasil" adalah orang yang menjalani kehidupannya sesuai rencana ilahi Allah. ${ }^{3}$ Dan juga manusia dikatakan benar jika bertindak selaras dengan tatanan atau perintah Allah maka manusia tersebut akan sejahtera dan bahagia, namun sebaliknya saat kehidupan manusia berlawanan dengan tatanan atau perintah-perintah Tuhan maka manusia dianggap salah dan menerima hal-hal yang tidak baik atau hukuman. ${ }^{4}$

Prinsip pembalasan atau disebut konsep retribusi ${ }^{5}$ adalah konsep dimana perbuatan manusia yang memberikan dampak positif atau negatif yang diterima diukur dari baik atau buruknya tindakan itu, seperti yang dikatakan oleh Jerome D. Quinn bahwa sudah secara umum diyakini bahwa Tuhan atau dewa-dewa yang diyakini akan ikut campur tangan dalam sejarah kehidupan manusia untuk

1 Took Hammond, Kunci Kekayaan (Jakarta: Light Publishing, 2005), 56.

2 Rene Girard, The idea of retribution [is] an essential aspect of every system of mythological representation [and it] dominates primitive religion" (Job: The Victim of His People (Stanford, CA: Stanford University Press, 1987), 122.

${ }^{3}$ Roy B. Zuck, A Biblical Theology Of The Old Testament (Malang: Gandum Mas, 2005), 381.

${ }^{4}$ Meno Soebagjo, Hormat Kepada TUHAN Dalam Sistem Pendidikan Kebijaksanaan Israel Kuno (Jakarta: PT Gramedia Widyaiswara Indonesia, 1994), 65.

${ }^{5}$ Andre E. Hill, Survei Perjanjian Lama (Malang: Gandum Mas, 2008), 240. 
menghargai kebaikan manusia dan memberikan hukuman kejahatan yang manusia lakukan. ${ }^{6}$ Immanuel Kant menyatakan bahwa satu-satunya bentuk dari hukuman pengadilan harus didasarkan pada konsep retribusi dan tidak ada prinsip lain, konsep ini berlaku pada semua kalangan pada saat manusia telah melakukan suatu kejahatan. ${ }^{7}$ Manusia yang hidupnya selaras dengan perintah-perintah Allah dapat menikmati kehidupan makmur dan sebaliknya manusia yang tidak menjalankan merasakan penderitaan dalam kehidupan. Ketidaktaatan menyebabkan manusia mengalami penderitaan di dalam kehidupan. Kemiskinan melanda mereka yang tidak taat. $^{8}$

Eichrodt menyatakan bahwa keyakinan tentang retribusi dapat ditemukan dalam teologi Israel, konsep tersebut melekat dalam teologi Perjanjian Lama. Konsep atau pandangan dari prinsip pembalasan ini bersifat universal, kehidupan yang berkelimpahan, berkemakmuran, sehat atau tidak mengalami sakit penyakit dan bahagia selalu diidentikan sebagai ciri-ciri orang benar. Tetapi orang miskin, sengsara, banyak penyakit dan mengalami banyak kerugian dikatakan sebagai orang fasik dan dipahami sangat wajar jika harus mengalami kondisi buruk. David J. A menyatakan bahwa konsep tersebut diyakini diselenggarakan di seluruh dunia kuno. ${ }^{9}$ Namun ada fakta-fakta yang menunjukkan bahwa ada orang-orang yang tetap taat pada perintah Tuhan namun masih mengalami penderitaan.

Kisah Joni Eareckson yang telah memberikan hidupnya untuk melayani Tuhan, mengalami sakit dan cacat fisik karena kecelakaan dan belum 1985), 84 .

6 Jerome D. Quinn, "The Scriptures of Merit," in Justification by Faith" (Minneapolis: Augs-burg, 7 Jacqueline Martin, The English Legal System (London: Hodder Arnold, 2005), 174.

8 Iwan Setiawan Elyon, The unstoppable Force for Prosperity (memahami kemakmuran sebagai Tradisi dalam kerajaan Allah) (Yogyakarta: Andi, 2014), 12.

${ }_{9}$ David J. A. Clines, Job 1-20, Word Biblical Commentary (Dallas: Word, 1989), xxxix. 
mendapatkan kesembuhan. ${ }^{10}$ Selanjutnya kisah Samuel Irwan, seorang pendeta yang tidak dapat menangis karena kelenjar air matanya tersumbat karena penyakit yang telah ia alami dahulu yaitu Stevens Johnson Syndrom (SJS). Seluruh badannya melepuh, hangus, bernanah dari ujung kepala sampai betis, badan yang penuh dengan borok yang menyebabkan tubuhnya hancur. Selain mengalami penyakit tersebut ia juga hidup dalam kemiskinan. Setelah itu Kisah John Piper yang kehilangan anak yang dikasihinya dan mengalami penyakit yaitu kanker prostat. Kisah pendeta David B. Biebel yang takut akan Tuhan dan dia mendedikasikan hidupnya untuk Tuhan yang mengalami sebuah penderitaan yang sangat berat, yaitu kehilangan anak yang bernama Yonatan pada awal Oktober 1978 karena penyakit yang disebabkan oleh infeksi virus. Selanjutnya tanggal 22 Agustus 1986 anak yang kedua bernama Christopher mengalami kerusakan otak yang dokter sebut leight dan akhirnya meninggal dunia. ${ }^{11}$ Kemudian kisah seorang wanita yang disiksa oleh tentara DII/TII pimpinan Kahar Muzakar yang menyiksa dan membunuh orang-orang Kristen. Dia mengalami penyiksaan yang begitu kejam, saudara dan ayahnya dibunuh di depan matanya karena menolak untuk menyangkal iman Kristen. Keluarganya adalah keluarga yang melayani Tuhan. ${ }^{12}$ Dan kisah para tokoh dalam perkembangan dan perubahan dunia, seperti tokoh martir abad 20 yaitu uskup Oscar Romero dalam perjuangan kebenaran dan Keadilan di tengah kekuasaan pemerintah El Salvador, penghapusan diskriminasi ras di Amerika Serikat Martin Luther King, Jr. Penolakan hollocaust atau

10 Joni Earecson Tada, Hikmat Seumur Hidup menikmati Cara Tuhan menyembuhkan Anda (Jakarta: Light Publishing, 2009), 78.

11 David B. Biebel, Kebaikan Allah vs penderitaan: suaktu kajian praktis tentang kebaikan Allah dalam penderitaan, trans. oleh Soemitro Onggosandojo, 1 ed. (Bandung: Kalam Hidup, 2008), 58.

12 Hermin Lambe-Sangka, Kesaksian Seorang Martir Rumah Seratus Jendela (Jakarta: BPK Gunung Mulia, 2001), 17-18. 
penganiayaan orang Yahudi oleh Dietrich Bonhoeffer. ${ }^{13}$ Mereka adalah orangorang yang telah memberikan hidup melakukan pekerjaan Tuhan namun mengalami penganiayaan dan penderitaan.

Realitas masa kini menunjukkan masih banyak penderitaan, kesusahan dan sakit penyakit yang dialami manusia. Salah satunya penderitaan akibat pandemi virus. Sejarah menunjukkan bahwa virus influenza merupakan salah satu pandemi terbesar yang pernah melanda dunia dan dapat dikatakan sebagai bencana terburuk yang disebabkan oleh virus. ${ }^{14}$ Selanjutnya pandemi lain yang terjadi telah mengancam kehidupan manusia seperti pandemi Pes yang juga pernah melanda Eropa menimbulkan penderitaan dan kematian banyak manusia serta mengancam peradaban manusia. ${ }^{15}$ Pada masa kini muncul pandemi Corona Viruses Desease 2019 (Covid-19) dari Wuhan China. ${ }^{16}$ Pandemi Covid-19 telah menyerang dan memberikan penderitaan kepada manusia, tidak hanya memberikan penderitaan secara fisik dan psikis namun juga materi. Pandemi Covid-19 telah menginfeksi lebih dari 215 negara di dunia dan menjadikan jutaan manusia menderita secara fisik bahkan kematian. ${ }^{17}$ Jutaan manusia menjadi korban keganasan dari Covid19. ${ }^{18}$ Jika diamati banyak pandemi terjadi tidak memandang apa latar belakang

13 Yusak Noven Susanto, "Pandangan Teologis Tentang Kehendak Bebas Manusia dan Relevansinya dengan kehidupan Orang Percaya Saat Ini," Journal of Chemical Information and Modeling 53, no. 9 (2017): 1689-99, https://doi.org/10.1017/CB09781107415324.004.

14 Edward C. Hutchinson, "Influenza Virus," Trends in Microbiology, 2018, 37.

15 Sharon N. DeWitte, "'Setting the Stage for Medieval Plague: Pre-Black Death Trends in Survival and Mortality," American Journal of Physical Anthropology, 2015, 53.

16 Nafilah Sri Sagita K, "Awal Mula Wabah COVID-19 di Wuhan Diklaim Berasal dari Makanan Beku Impor," health.detik.com, Detik Health, 12 Agustus 2020, https://health.detik.com/berita-detikhealth/d5286363/awal-mula-wabah-covid-19-di-wuhan-diklaim-berasal-dari-makanan-beku-impor.

17 Gaurav Das, Nabanita Mukherjee, and Surajit Ghosh, "Neurological Insights of COVID-19 Pandemic (ACS Chemical Neuroscience, 2020), 18.

18 Endah Christina, "Pandemi Covid-19 Adalah 666?," Logia: Jurnal Teologi Pentakosta 1, no. 2 (2020): 1-22, https://doi.org/10.37731/log.v1i2.40. 
orang yang mengalami penderitaan itu. Pandemi yang menerpa baik kepada orang yang saleh, orang baik, orang jahat, orang kaya dan orang miskin.

Dengan demikian fakta-fakta tersebut menunjukkan ada gap antara konsep prinsip pembalasan atau konsep retribusi terhadap realitas yang ada. Justru ada banyak manusia yang taat kepada perintah Tuhan tetap mengalami penderitaan, kesakitan, kegagalan dan kehilangan. Oleh karena itu sangat penting untuk memahami tentang konsep retribusi dalam menjawab realitas yang terjadi pada masa kini secara khusus fenomena pademi covid-19.

\section{METODE}

Metode penelitian ini adalah metode kualitatif dengan pendekatan tinjauan teologis. ${ }^{19}$ Metode tinjauan teologis merupakan metode yang melakukan tinjaun teologis terhadap fakta-falta yang terjadi serta melakukan analisis sebuah konsep teologi, dalam tulisan ini secara khusus menganalisis tentang teologi pembalasan. Peneliti membatasi penelitian ini dalam ruang lingkup pandemi covid-19 dengan prinsip pembalasan. Langkah-langkah dalam penelitian ini yaitu: penulis mengumpulkan data-data dari berbagai sumber literatur. Peneliti menggunakan pendekatan tinjauan teologis, dalam pembahasan akan dibahas mengenai prinsip pembalasan, sebagai tesis yang memiliki anti tesis yaitu fakta yang ada. Kemudian menganalisis gap dengan anti tesis yang ada dan menyimpulkan seluruh pembahasan serta memberikan relevansinya dengan konteks gereja di Indonesia.

\section{HASIL}

Penelitian ini menghasilkan beberapa konsep penting, pertama, Kitabkitab sastra atau puisi banyak menyajikan konsep tentang teologi pembalasan atau

19 Handi Hadiwitanto, "Metode Kuantitatif dalam Teologi Praktis," GEMA TEOLOGIKA 2, no. 1 (28 April 2017): 1, https://doi.org/10.21460/gema.2017.21.291. 
retribusi. Kedua, pandemi Covid-19 yang melanda banyak Negara dan tidak memandang siapa yang harus kena apakah itu orang jahat, atau orang baik, orang saleh, orang kaya atau miskin semua dapat terkena virus yang berbahaya ini. Ketiga, Pandemi Covid-19 dapat mematahkan atau dapat meredefinisi konsep prinsip pembalasan, konsep tersebut menjadi seperti tidak relevan pada suatu kasus tertentu, konsep tersebut tidak lagi dapat diterapkan secara umum karena fakta yang ada telah membuktikan bahwa tidak selamanya manusia yang menderita atau mengalami hal-hal buruk itu karena dosanya. Keempat, Pandemi Covid 19 adalah suatu Pandemi yang Tuhan izinkan, maka prinsip pembalasan tidak relevan jika diterapkan pada pandemi Covid-19. Kelima, Penderitaan orang benar merupakan suatu permasalahan yang tidak logis, namun dalam penderitaan orang benar tidak lepas dari pengaturan dan tidak kedaulatan Allah.

\section{PEMBAHASAN}

Prinsip pembalasan tidak dapat dilepaskan dari sastra hikmat, kehidupan yang makmur, hidup bahagia dipenuhi dengan berkat dan orang fasik akan mengalami penderitaan atau kutukan. Di dalam sastra hikmat prinsip pembalasan lebih cenderung dibahas dalam kitab Ayub, Amsal, Pengkhotbah dan Mazmur. ${ }^{20}$ Hubbard menyatakan bahwa sastra hikmat merupakan ragam sastra yang lazim di Timur dekat Kuno. Sastra yang memberikan petunjuk untuk mencapai kehidupan yang berhasil dan menjawab permasalahan-permasalahan hidup yang disebabkan oleh kebingungan-kebingungan. ${ }^{21}$ Cara yang digunakan untuk menyampaikan

\footnotetext{
20 Gordon D.Fee dan Douglas Struart, Hermeneutik bagaimana menafsirkan Firman Tuhan dengan Tepat (Malang: Gandum Mas, 2001), 218.

21 Hubbard, The New Bible Dictionary (California: World Pub, 1991), 1334.
} 
pesan dari hikmat tersebut dengan menggunakan peribahasa-peribahasa yang singkat dan tajam dan bersifat spekulatif. ${ }^{22}$

Kata hikmat sesuai konteksnya mengacu kepada keahlian atau kecakapan seseorang dalam menguasai suatu pekerjaan, contoh penjahit yang ahli membuat baju Harun dan para pekerja Bait Suci (Kel. 28: 3). ${ }^{23}$ Manusia membutuhkan pengetahuan praktis dan pengetahuan hukum kehidupan yang berdasarkan pengalaman untuk memiliki hidup yang sepantasnya, demikian yang diungkapkan oleh Von Rad. $^{24}$ Contoh-contoh tema dalam Sastra hikmat adalah pertama, masalah hukuman. Kedua, pembagian antara yang benar dan yang jahat. Ketiga, nasihat untuk percaya secara pribadi kepada Tuhan. Keempat, takut akan Tuhan. Kelima, perenungan akan hukum tertulis Allah sebagai sumber kesukaan. ${ }^{25}$

Prinsip pembalasan di dalam sastra hikmat merupakan prinsip yang lazim pada masa Perjanjian Lama dan suatu pembahasan yang umum dalam kitab puisi dan sastra hikmat dalam PL. Prinsip ini terlihat jelas di dalam kutukan-kutukan dan berkat-berkat dalam perjanjian Musa. Prinsip pembalasan sangat berkaitan dengan sikap takut akan Tuhan yang telah dibahas di atas, dalam konsep ini seseorang harus menerima ganjaran atau suatu pertanggung jawaban yang setimpal dengan apa yang telah diperbuatnya, dunia merupakan tempat untuk melaksanakan pembalasan tersebut. Dalam prinsip pembalasan ini terdapat adanya korespondensi antara tindakan yang dilakukan oleh seseorang dengan nasibnya. ${ }^{26}$

${ }^{22}$ Claire Mathews McGinnis dkk., "Theological Dictionary of the Old Testament," Journal of Biblical Literature, 2006, https://doi.org/10.1093/oxfordhb/9780199204540.003.0007.

${ }^{23}$ Roy B. Zuck, A Biblical Theology Of The Old Testament, 79.

24 Gerhard Von Rad, Old Testament Theology vol 2 (New York: Harper \& Row, 1967), 418.

25 David G. Firth dan and Lindsay "Wilson, EXPLORING OLD TESTAMENT WISDOM (England: Literature and themes, 2016), 69.

${ }^{26}$ McGinnis dkk., "Theological Dictionary of the Old Testament" 54. 
Konsep Keadilan Allah itu terwujud dalam konsep retribusi atau prinsip pembalasan. Perjanjian Lama memposisikan Allah sebagai pribadi yang melepaskan orang yang mengalami penindasan. Bangsa Israel adalah saksi hidup yang mengalami kuasa pembebasan dari perbudakan, pengalaman mereka menjadi dasar untuk konsep prinsip pembalasan, saat taat mereka tidak mendapatkan hukuman, namun sebaliknya saat mereka tidak taat mereka menerima murka Allah, dan itu merupakan suatu konsekuensi logis yang harus diterima bahkan turun temurun. $^{27}$

Pandangan yang menjelaskan kemakmuran orang benar adalah suatu keseharusan dan kehidupan orang fasik seharusnya mengalami penderitaan, dijelaskan sangat bagus sekali oleh Andre Hill dimana Allah tidak perlu turun tangan langsung, karena perbuatan manusia tersebut yang menentukan berkat dan kutuk yang akan diterima orang tersebut. Perbuatan yang bijaksana akan mendatangkan kemakmuran, sementara perbuatan bodoh yang akan mendatangkan kehancuran (Ams. 1-9; 26: 27). ${ }^{28}$ Kitab-kitab puisi sering kali membahas mengenai Prinsip pembalasan, seperti Kitab Ayub, kitab yang diklaim kitab paling tua ini alasannya yaitu penulisannya diprediksikan di zaman para Bapak Leluhur. ${ }^{29}$ Dengan pendekatan teologis berupa pandangan universal seperti pada keadilan atau kejahatan atau penderitaan yang tidak patut dan tidak pantas. Kitab Ayub menjelaskan pandangan prinsip pembalasan dinyatakan dengan kalimat: jika seorang hidup benar, dia akan makmur jika orang hidup jahat maka orang tersebut akan menderita. Konsep ini menjadi premis dasar yang menyatakan

${ }_{27}$ McGinnis dkk., 89.

28 Walter Brueggemann, Teologi Perjanjian Lama: Kesaksian, Tangkisan, Pembelaan (Maumere: Ledalero, 2009), 515.

29 William Sanford La Sor dkk., Pengantar Perjanjian Lama 2: Sastra dan Nubuat, 1994, 84. 
bahwa orang yang memiliki kehidupan yang baik, sehat, sejahtera, tidak ada masalah tentu ini adalah hidup dari orang benar, berbeda lagi dengan pribadipribadi yang memiliki kehidupan penuh dengan penderitaan maka berarti orangorang tersebut adalah orang berdosa atau fasik.

Dalam kitab Ayub terlihat ungkapan-ungkapan dari sahabat-sahabat Ayub yang menyudutkan dan menyatakan bahwa Ayub tidak taat atau tidak takut akan Tuhan. Allah memiliki sifat yang adil sehingga apa yang sedang terjadi adalah suatu bentuk Keadilan Allah yang sesuai dengan perbuatan yang dilakukan orang tersebut. Tuhan berkenan memberikan berkat dan kemakmuran kepada orang benar dan memberikan kutukan kepada orang fasik, pandangan ini sudah sangat mendarah daging sehingga mereka tidak dapat melihat kemungkinan lain dari peristiwa tersebut. ${ }^{30}$

Kitab Amsal tidak terlepas dari prinsip pembalasan yang menyatakan berkat dan kutuk. Sebuah konsep yang mengajarkan tentang pengharapan adanya pahala dan berkat karena bangsa tersebut hidup sesuai dengan hukum-hukum yang telah ditetapkan bagi mereka yang taat kepada Tuhan dan layak untuk menerimanya. Penekanan terhadap kepatuhan dan kesetiaan itu merupakan kehidupan orang saleh dan perilaku yang benar, adil dan jujur menghasilkan keuntungan-keuntungan berupa kemakmuran, damai sejahtera, kesehatan dan panjang umur. Hal-hal tersebut sangat erat sekali kaitannya dengan Perjanjian TUHAN. ${ }^{31}$ Prinsip Pembalasan dalam kitab Amsal ini sangat kental, ada ganjaran dari Allah bagi mereka yang melakukan perbuatan baik dan menghukum

30 S.W. Wahono, Di sini kutemukan: petunjuk mempelajari dan mengajarkan alkitab (Jakarta: BPK Gunung Mulia, 1986), 227.

${ }^{31}$ Andrew E. Hill, Survei Perjanjian Lama. Edisi Revisi, 3 ed. (Malang: Gandum Mas, 2013), 479. 
perbuatan yang jahat, ada konsekuensi yang manusia terima dan itu mutlak (Ams. 13: 3). ${ }^{32}$ Dalam Kitab Amsal prinsip pembalasan tidak hanya berkaitan dengan aspek kerohanian atau agama saja namun berkaitan dengan berbagai aspek kehidupan. Sangat jelas dalam kitab ini bahwa perbuatan yang bijaksana mendatangkan kemakmuran, sementara perbuatan bodoh mendatangkan kehancuran (Ams. 1-9; 26: 27) ${ }^{33}$ Hikmat memiliki peranan penting dalam jalan kehidupan, perbuatan-perbuatan baik tersebut menghasilkan sesuatu yang baik yang pantas untuk diterima.

Kitab Pengkhotbah menyuguhkan fakta bahwa Allah akan memberikan pahala kepada orang benar dan menghukum orang fasik dalam kekekalan ( Pkh. 3: 16-22; 8: 10-14; 7: 15-17 dan 9: 1-6). ${ }^{34}$ Ada wewenang Allah yang harus ditaatin jika dilanggar maka orang yang melanggar menerima konsekuensi. Maka jika seseorang hidup di jalan yang telah ditetapkan dan dengan melibatkan Tuhan di dalam kehidupannya Allah memberikan suka cita di dalam setiap aspek kehidupan manusia dari makanan, pekerjaan, rumah tangga dan pernikahan (Pkh. 2: 24-26; 3: 10-15; 5: 17-19). Allah akan mengadili orang yang benar dan yang salah sesuai dengan perbuatannya. ${ }^{35}$

Kitab Mazmur pasal 1 telah menunjukkan kontras antara orang benar dan orang fasik. Dituliskan bahwa orang fasik menerima penghukuman selamalamanya dan tidak terlepas dari penderitaan. Hal ini merupakan Keadilan Allah yang sangat diyakini oleh umat Israel (Mzm. 27: 13; 91: 5-8), sehingga prinsip 19.

32 Richard J. Clifford, Proverbs: A Commentary (Louisville: Westminster John Konx Press, 1999), 33 Walter Brueggemann, Teologi Perjanjian Lama: Kesaksian, Tangkisan, Pembelaan (Maumere: Ledalero, 2009), 519.

${ }^{34}$ Hill, Survei Perjanjian Lama. Edisi Revisi, 451.

35 Ny Yap Wei Fong, Pedoman lengkap pendalaman Alkitab (Bandung: Kalam Hidup, 2002), 38. 
pembalasan menjadi sangat serius bagi mereka. Jika melihat dalam Mazmur ratapan, Pemazmur menganggap bahwa dirinya lebih benar dari pada musuhmusuhnya sehingga meminta Tuhan memperhitungkannya dan dapat memberikan perlakuan yang setimpal dengan perbuatan mereka. Pandangan dari pemazmur yang meratap ini terlihat bahwa ada sesuatu yang tidak dia terima yaitu saat orang fasik memperoleh kehidupan yang makmur atau hanya memperoleh penghukuman yang ringan, karena Allah adil maka sudah selayaknya orang fasik menderita sebanding dengan apa yang diperbuatnya dan orang benar memperoleh kehidupan yang makmur. Dalam kitab Mazmur penghukuman bagi orang yang fasik adalah suatu hal yang umum (Mzm. 28: 4) dan terkadang juga bersifat khusus (Mzm.137: 9). Contoh yang sangat jelas terlihat di dalam Mazmur 58 dan 109 yang menjelaskan bahwa seseorang layak menerima sesuatu yang sepantasnya diterima sesuai dengan perbuatan mereka. Hukuman yang pantas diberikan kepada para orang fasik dengan tujuan untuk menunjukkan betapa jahatnya mereka, semakin parah hukuman yang diterima maka menunjukkan semakin jahatnya orang tersebut. Kitab Mazmur ini menurut Andre Hill membenarkan apabila orang yang benar mengharapkan Allah memberkati mereka dengan kemakmuran karena kebenaran dan perbuatan baik mereka. Dengan demikian Penjelasan dari keempat kitab sastra tersebut memberikan pengertian bahwa formula yang terkandung di dalam setiap pandangan kitab adalah sama yaitu terdapat konsekuensi logis yang sama di setiap kitabnya. Orang benar akan memperoleh berkat dan hidup penuh kemakmuran sementara orang fasik akan menerima kutuk dan penderitaan. 
Corona Virus merupakan suatu fakta yang tidak dapat ditolak sekalipun banyak spekulasi, namun yang jelas virus telah menjadi suatu bencana yang bersifat menyeluruh dan banyak negara mengalami musibah. Covid-19 termasuk dalam golongan keluarga besar virus yang berdampak memberikan penyakit dengan intensitas yang ringan sampai yang berat, jika ringannya itu seperti common cold atau pilek dan yang berat dapat menyebabkan penyakit serius seperti Middle East Respiratory Syndrome (MERS) dan Severe Acure Respiratory Syndrome (SARS). Penularan dapat terjadi dari hewan ke manusia (zoonosis). Cara penularan virus ini juga beragam yaitu dapat melalui hewan ke manusia atau dari manusia ke manusia. ${ }^{36}$ Dalam sejarah awal mula virus ini diindikasikan berasal dari kota Wuhan pada akhir tahun 2019. Dampak yang ditimbulkan oleh virus ini meliputi kondisi kesehatan bahkan sektor lain juga mendapatkan dampak, seperti pendidikan, ekonomi dan sosial hingga pada religiositas. ${ }^{37}$ Dengan cepatnya menyebar virus ini menjadikan bencana ini bukanlah bencana lokal bencana ini lebih bersifst multidimensional dan tersebar hampir di seluruh wilayah. Dari sudut pandang yang berbeda ada dua ruang lingkup yang terdampak luar biasa, yaitu aktor (level of analysis) dan aspek (aspects or issues). ${ }^{38}$ Pada 29 Desember 2020 data menunjukkan 82.8M kasus dengan Recovered 46.8M, Deaths $1.81 \mathrm{M} .^{39}$ Dari banyaknya kasus yang terjadi virus corona tidak memandang latar belakang manusia. Banyak Pendeta yang

\footnotetext{
${ }^{36}$ PH Livana dkk., "Dampak pandemi COVID-19 bagi perekonomian masyarakat desa," Indonesian Journal of Nursing and Health Sciences 1, no. 1 (2020): 37-48.

${ }^{37}$ Suprayoga Hadi, "Pengurangan Risiko Pandemi Covid-19 Secara Partisipatif: Suatu Tinjauan Ketahanan Nasional terhadap Bencana," Jurnal Perencanaan Pembangunan: The Indonesian Journal of Development Planning 4, no. 2 (2020): 177-90, https://doi.org/10.36574/jpp.v4i2.109.

${ }^{38}$ Anggia Valerisha dan Marshell Adi Putra, "Pandemi Global Covid-19 Dan Problematika NegaraBangsa: Transparansi Data Sebagai Vaksin Socio-Digital?," Jurnal Ilmiah Hubungan Internasional 0, no. 0 (2020): 131-37, https://doi.org/10.26593/jihi.v0i0.3871.131-137.

${ }^{3}$ N N, "Virus Corona (Covid-19)," news.google.com, Goggle Berita, 29 Desember 2020, https://news.google.com/covid19/map?hl=id\&gl=ID\&ceid=ID\%3Aid.
} 
dikabarkan terpapar covid-19, salah satunya kasus pendeta di Batam yang terapapar covid-19 dan menyebar kepada puluhan jemaat. ${ }^{40}$ Pademi covid-19 berdampak kepada pembatasan cara beribadah secara tatap muka baik di gereja dan agama-agama lain di Indonesia.

Selain itu covid-19 juga berdampak pada sektor ekonomi, Menteri keuangan Indonesia Sri Muliayani menyatakan ada dampak besar ke ekonomi Indonesia karena pandemi covid-19 yaitu, pertama, jual beli mengalami penurunan yang sangat drastic, 60\% penopang ekonomi yaitu konsumsi mengalami kejatuhan. Kedua, investasi mengalami kelemahan sangat parah karena banyaknya ketidakpastian. Ketiga, ekspor seluruh dunia mengalami melemah. ${ }^{41}$ Selanjutnya terjadi peningkatan pengangguran yang sangat signifikan karena PHK (Pemutusan Hubungan Kerja). ${ }^{42}$ Dua Negara Adidaya yang berkuasa dalam sektor ekonomi di dunia yaitu Amerika Serikat dan Tiongkok diproyeksi kuat mengalami kemerosotan ekonomi akibat pandemi covid-19. ${ }^{43}$ Fakta-fakta tersebut menunjukkan dampak covid-19 tidak hanya menyerang atau menjangkit kepada orang yang tidak taat kepada Allah, namun kepada semua orang. ${ }^{44}$ Covid19 memberikan sebuah realitas bahwa prinsip pembalasan kurang tepat ditujukan

\footnotetext{
40 Chandra Iswinarno, "Pendeta di Batam Meninggal Terkena Corona, Puluhan Jemaat Jalani Karantina," $\quad$ www.suara.com, $\quad$ Suara.Com, 23 Maret https://www.suara.com/news/2020/03/23/073209/pendeta-di-batam-meninggal-terkena-corona-puluhanjemaat-jalani-karantina?page=all.

41 Johan Tallo, "Sri Mulyani: Corona Beri 3 Dampak Besar ke Ekonomi Indonesia," www.liputan6.com, Liputan 6, 30 Juni 2020, https://www.liputan6.com/bisnis/read/4292763/sri-mulyanicorona-beri-3-dampak-besar-ke-ekonomi-indonesia.

42 Peter Garlans Sina, "Ekonomi Rumah Tangga Di Era Pandemi Covid-19," Journal of Management: Small and Medium Enterprises (SMEs) 12, no. 2 (2020): 239-54, https://doi.org/10.35508/jom.v12i2.2697.

43 Sri Maryani, I Gusti Ayu Oka Netrawati, dan I Wayan Nuada, "Pendemi Covid-19 dan Implementasinya pada Perekonomian NTB," Jurnal Binawakya 14, no. 11 (2020): 3497-3508. https://doi.org/10.33758/mbi.v14i10.573

44 Richard J. Clifford, Wisdom Literature In Mesopotamia And Israel (Atlanta: Society of Biblical Literature, 2007), 71.
} 
kepada orang-orang terdampak covid-19, karena konsep tersebut mendasarkan pada konsep bahwa orang taat, baik, saleh dan jujur mendapatkan berkat, namun orang-orang yang tidak baik, jahat dan tidak taat mendapatkan hukuman atau kutukan.

Kisah Ayub adalah salah satu contoh mengenai penderitaan yang tidak sesuai dengan keharusan konsep dasar dari Prinsip Pembalasan. Konsep retribusi tidak berlaku bagi kehidupan Ayub, karena latar belakang kehidupan Ayub yang benar di hadapan Tuhan. Ayub mengalami penderitaan tidak pada tempatnya, jika dilihat dari pengertian konsep retribusi dan yang diyakini para sahabat Ayub yang seharusnya Ayub terima bukanlah penderitaan. Ayub mengalami penderitaan secara fisik, emosi dan tekanan mental serta kecemasan. ${ }^{45}$ Penderitaan yang Ayub alami menjadi sebuah tuduhan para sahabat Ayub yang mewakili pandangan masyarakat umum yang memegang konsep retribusi atau prinsip pembalasan, sehingga menuntut Ayub harus segera bertobat dari kefasikan dan keberdosaan nya.

Para murid Yesus mengalami penderitaan dan penganiayaan, Stefanus menjadi martir karena pemberitaan Firman Tuhan dan meninggal pada tahun 35 M karena dilempari dengan batu. Peristiwa yang dialaminya menjadi awal penyiksaan yang sadis dan mengerikan kepada jemaat di Yerusalem (Kis. 8: 1). Para murid Tuhan Yesus mengalami penderitaan dan kematian yang mengerikan, seperti kematian Yakobus saudara rasul Yohanes (Kis. 12:2). Pemerintahan Raja Herodes Agripa I terjadi penyiksaan dengan cambukan dan berakhir mati di salib. 
Rasul Matius pada saat dia melayani di daerah Ethiopia mengalami pemancungan pada tahun 60 Masehi. Tradisi gereja mencatat Yakobus saudara Yesus dan penulis surat Yakobus mati dengan cara dirajam batu. Matias dirajam batu dan dipancung. Rasul Andreas mati dengan cara di salibkan berbentuk X. Rasul Markus tubuhnya terkoyak-koyak karena diseret. Rasul Petrus mati disalib dengan posisi terbalik. Rasul Paulus mati dengan hukum pancung. Dengan demikian tidak selalu hidup benar dan memiliki persekutuan yang baik dan intim dengan Tuhan menjadikan hidup makmur dan bahagia, maka konsep prinsip pembalasan tidak sesuai dengan fakta kehidupan para Murid Yesus di dalam Alkitab.

Dengan melihat fakta-fakta mengenai orang-orang benar seperti Ayub, para Rasul yang menerima penderitaan dan kematian yang tidak layak diterima. Demikian juga orang-orang benar seharusnya tidak terjangkit Covid-19, namun fakta menunjukkan orang benar tetap terkena paparan covid-19. Fakta-fakta orang benar yang menderita covid-19 dapat menjadi suatu dekonstruksi dan rekonstruksi konsep prinsip pembalasan yang selama ini diyakini. Rabi Kushner mengatakan bahwa konsep pembalasan bukanlah konsep yang kaku, namun konsep tersebut harus dilihat secara menyeluruh terhadap siapa yang mengalaminya. ${ }^{46}$ Penderitaan yang dialami oleh orang benar karena pandemi covid-19 tidak merupakan kutukan atau hukuman dari Tuhan. Allah adalah Pribadi yang adil Dia akan konsisten dengan apa yang difirmankan, Allah tidak akan melanggar kepribadian-Nya sendiri, apapun yang Allah kerjakan itu adalah wujud keadilan-Nya dengan demikian dapat dikatakan bahwa orang yang menderita tidak selamanya karena dosa. 112.

${ }^{46}$ Harold S. Kushner, When Bad Things Happen To Good People (New York: Avon Books, 1983), 
Dengan demikian prinsip pembalasan tidak relevan untuk menjadi standar mutlak bahwa orang benar diberkati dan orang fasik dikutuk. Dalam keadilan Allah bagi orang benar yang menderita sekalipun dalam konteks ketidak berdosaannya, orang tersebut menderita dalam naungan keadilan Allah. Keadilan Allah dalan penderitaan yang tidak logis tersebut merupakan cara Allah menunjukan keadilan dari cara-Nya, dimana orang menderita tersebut sedang dalam pembelaan Tuhan. Penderitaan yang tidak logis ini merupakan alat atau sarana untuk menunjukkan atau menyatakan sifat Allah yang adil, sekalipun yang bertentangan dengan kenyataan yang ada. Penderitaan tidak akan pernah terjadi tanpa seizin Allah. Sebagaimana Ayub menderitaan karena perbuatan Iblis itu karena Allah yang mengizinkan hal itu terjadi (Ay. 1: 12; 2: 6). Kekudusan dan kedaulatan Allah adalah bagian di mana manusia yang ada tidak dapat mengganggu gugat keadaan ini, dan hal tersebut adalah mutlak. Di dalam kekudusan dan kedaulatan Allah tersimpan berbagai sifat dasar Allah yang memang pada dasarnya selalu konsisten tidak akan pernah berubah.

\section{KESIMPULAN}

Berdasarkan pembahasan di atas maka penulis menarik kesimpulan bahwa konsep prinsip pembalasan tidak dapat ditetapkan secara general. Karena fakta menunjukkan orang benar, orang saleh dan orang baik mengalami penderitaan. Konsep retribusi atau prinsip pembalasan adalah taat mendapat berkat dan tidak taat mendapatkan kutuk, namun faktanya orang-orang yang terdampak covid-19 bukanlah orang jahat di dalamnya ada juga orang-orang benar dan taat kepada Tuhan. Penderitaan yang terjadi karena covid-19 karena Tuhan yang mengizinkan penderitaan itu. Dan bertujuan untuk mendatangkan kebaikan dan menyatakan 
kuasa Tuhan. Dalam kesimpulan ini penulis menyarankan kepada orang percaya dalam menyikapi pendemi covid-19, baik yang terkena penyakit ataupun dampak dari pandemi secara tidak langsung, pandemi yang terjadi tidaklah lepas dari pengaturan dan kedaulatan Tuhan. Jika memang orang percaya mengalami pandemi dan dampaknya itu karena Tuhan mengizinkan hal tersebut terjadi. Tuhan tidak akan meninggalkan orang percaya yang dikasihi menghadapi pandemi ini sendiri. Ayub Tuhan izinkan mengalami penderitaan yang mengerikan namun Tuhan tidak meninggalkannya, begitu juga orang percaya pada masa kini Tuhan memegang kendali, Tuhan tidak akan meninggalkan. Dalam kedaulatan Tuhan tidak ada rencana Tuhan yang mendatangkan kecelakaan. Rencana Tuhan adalah rencana yang baik, jika ada hal yang tidak baik terjadi maka Dia adalah Tuhan yang turut bekerja dalam segala hal untuk mendatangkan kebaikan. Ada rencana Indah dan baik dibalik setiap peristiwa yang Tuhan izinkan terjadi termasuk dalam Pandemi Covid-19 ini.

\section{DAFTAR PUSTAKA}

Andre E. Hill. Survei Perjanjian Lama. Malang: Gandum Mas, 2008.

Biebel, David B. Kebaikan Allah vs penderitaan: suaktu kajian praktis tentang kebaikan Allah dalam penderitaan. Diterjemahkan oleh Soemitro Onggosandojo. 1 ed. Bandung: Kalam Hidup, 2008.

Brueggemann, Walter. Teologi Perjanjian Lama: Kesaksian, Tangkisan, Pembelaan. Maumere: Ledalero, 2009.

Christina, Endah. "Pandemi Covid-19 Adalah 666?" Logia: Jurnal Teologi Pentakosta 1, no. 2 (2020): 1-22. https://doi.org/10.37731/log.v1i2.40.

David J. A. Clines. Job 1-20, Word Biblical Commentary. Dallas: Word, 1989.

Earecson Tada, Joni. Hikmat Seumur Hidup menikmati Cara Tuhan menyembuhkan Anda. Jakarta: Light Publishing, 2009.

Edward C. Hutchinson. “Influenza Virus,” Trends in Microbiology, 2018. 
Firth, David G., dan and Lindsay "Wilson. EXPLORING OLD TESTAMENT WISDOM. England: Literature and themes, 2016.

Gaurav Das. Nabanita Mukherjee, and Surajit Ghosh, "Neurological Insights of COVID-19 Pandemic. ACS Chemical Neuroscience, 2020.

Gerhard Von Rad. Old Testament Theology vol 2. New York: Harper \& Row, 1967.

Gordon D.Fee dan Douglas Struart. Hermeneutik bagaimana menafsirkan Firman Tuhan dengan Tepat. Malang: Gandum Mas, 2001.

Hadi, Suprayoga. "Pengurangan Risiko Pandemi Covid-19 Secara Partisipatif: Suatu Tinjauan Ketahanan Nasional terhadap Bencana." Jurnal Perencanaan Pembangunan: The Indonesian Journal of Development Planning 4, no. 2 (2020): 177-90. https://doi.org/10.36574/jpp.v4i2.109.

Hadiwitanto, Handi. "Metode Kuantitatif dalam Teologi Praktis." GEMA TEOLOGIKA 2, no. 1 (28 April 2017): 1. https://doi.org/10.21460/gema.2017.21.291.

Hill, Andrew E. Survei Perjanjian Lama. Edisi Revisi. 3 ed. Malang: Gandum Mas, 2013.

Hubbard. The New Bible Dictionary. California: World Pub, 1991.

Iswinarno, Chandra. "Pendeta di Batam Meninggal Terkena Corona, Puluhan Jemaat Jalani Karantina." Www.suara.com. Suara.Com, 23 Maret 2020. https://www.suara.com/news/2020/03/23/073209/pendeta-di-batammeninggal-terkena-corona-puluhan-jemaat-jalani-karantina?page=all.

Iwan Setiawan Elyon. The unstoppable Force for Prosperity (memahami kemakmuran sebagai Tradisi dalam kerajaan Allah). Yogyakarta: Andi, 2014.

J. Clifford, Richard. Proverbs: A Commentary. Louisville: Westminster John Konx Press, 1999.

Jacqueline Martin. The English Legal System. London: Hodder Arnold, 2005.

Jerome D. Quinn. "The Scriptures of Merit," in Justification by Faith". Minneapolis: Augs-burg, 1985.

La Sor, William Sanford, David Allan Hubbard, Frederic Wm Bush, Lisda T. Gamadhi, dan Lily W. Tjiputra. Pengantar Perjanjian Lama 2: Sastra dan Nubuat, 1994.

Lambe-Sangka, Hermin. Kesaksian Seorang Martir Rumah Seratus Jendela. Jakarta: BPK Gunung Mulia, 2001. 
Livana, PH, Resa Hadi Suwoso, Terri Febrianto, Dani Kushindarto, dan Firman Aziz. "Dampak pandemi COVID-19 bagi perekonomian masyarakat desa." Indonesian Journal of Nursing and Health Sciences 1, no. 1 (2020): 37-48.

Maryani, Sri, I Gusti Ayu Oka Netrawati, dan I Wayan Nuada. "Pendemi Covid19 dan Implementasinya pada Perekonomian NTB.” Jurnal Binawakya 14, no. 11 (2020): 3497-3508. https://doi.org/10.33758/mbi.v14i10.573

McGinnis, Claire Mathews, Dale C. Allison, Walter Brueggemann, Tod Linafelt, T Desmond Alexander, David W Baker, James Barr, dkk. "Theological Dictionary of the Old Testament." Journal of Biblical Literature, 2006. https://doi.org/10.1093/oxfordhb/9780199204540.003.0007.

Meno Soebagjo. Hormat Kepada TUHAN Dalam Sistem Pendidikan Kebijaksanaan Israel Kuno. Jakarta: PT Gramedia Widyaiswara Indonesia, 1994.

N, N. "Virus Corona (Covid-19)." News.google.com. Goggle Berita, 29 Desember 2020. https://news.google.com/covid19/map?hl=id\&gl=ID\&ceid=ID\%3Aid.

Pakpahan, Gernaida, Sekolah Tinggi, dan Teologi Bethel. "Kecemasan Mahasiswa STT Bethel Indonesia terhadap Covid-19" 3, no. 1 (2020): 2033. https://doi.org/10.32490/didaktik.v3i1.35

Rene Girard. The idea of retribution [is] an essential aspect of every system of mythological representation [and it] dominates primitive religion" (Job: The Victim of His People. Stanford, CA: Stanford University Press, 1987.

Richard J. Clifford. WISDOM LITERATURE IN MESOPOTAMIA AND ISRAEL. Atlanta: Society of Biblical Literature, 2007.

Roy B. Zuck. A Biblical Theology Of The Old Testament. Malang: Gandum Mas, 2005.

S. Kushner, Harold. When Bad Things Happen To Good People. New York: Avon Books, 1983.

Sharon N. DeWitte. "“'Setting the Stage for Medieval Plague: Pre-Black Death Trends in Survival and Mortality." American Journal of Physical Anthropology, 2015.

Sina, Peter Garlans. "Ekonomi Rumah Tangga Di Era Pandemi Covid-19." Journal of Management: Small and Medium Enterprises (SMEs) 12, no. 2 (2020): 239-54. https://doi.org/10.35508/jom.v12i2.2697.

Sri Sagita K, Nafilah. "Awal Mula Wabah COVID-19 di Wuhan Diklaim Berasal dari Makanan Beku Impor.” Health.detik.com. Detik Health, 12 Agustus 
2020. https://health.detik.com/berita-detikhealth/d-5286363/awal-mulawabah-covid-19-di-wuhan-diklaim-berasal-dari-makanan-beku-impor.

Susanto, Yusak Noven. "Pandangan Teologis Tentang Kehendak Bebas Manusia dan Relevansinya dengan kehidupan Orang Percaya Saat Ini." Journal of Chemical Information and Modeling 53, no. 9 (2017): 1689-99. https://doi.org/10.1017/CBO9781107415324.004.

Tallo, Johan. "Sri Mulyani: Corona Beri 3 Dampak Besar ke Ekonomi Indonesia." Www.liputan6.com. Liputan 6, $30 \quad$ Juni 2020. https://www.liputan6.com/bisnis/read/4292763/sri-mulyani-corona-beri-3dampak-besar-ke-ekonomi-indonesia.

Took Hammond. Kunci Kekayaan. Jakarta: Light Publishing, 2005.

Valerisha, Anggia, dan Marshell Adi Putra. "Pandemi Global Covid-19 Dan Problematika Negara-Bangsa: Transparansi Data Sebagai Vaksin SocioDigital?" Jurnal Ilmiah Hubungan Internasional 0, no. 0 (2020): 131-37. https://doi.org/10.26593/jihi.v0i0.3871.131-137.

Wahono, S.W. Di sini kutemukan: petunjuk mempelajari dan mengajarkan alkitab. Jakarta: BPK Gunung Mulia, 1986.

Walter Brueggemann. Teologi Perjanjian Lama: Kesaksian, Tangkisan, Pembelaan. Maumere: Ledalero, 2009.

Yap Wei Fong, Ny. Pedoman lengkap pendalaman Alkitab. Bandung: Kalam Hidup, 2002. 